\title{
Mitochondrial DNA Variants in a Portuguese Population of Patients with Alzheimer's Disease
}

\author{
Manuela Grazina ${ }^{a, b}$ Filipe Silva ${ }^{b, c}$ Isabel Santana ${ }^{c}$ João Pratas ${ }^{b}$ \\ Beatriz Santiago $^{c}$ Miguel Oliveira $^{b}$ Isabel Carreira ${ }^{a}$ Luís Cunha $^{b}$ c \\ Catarina Oliveira ${ }^{\mathrm{a}-\mathrm{c}}$ \\ ${ }^{a}$ Faculty of Medicine, University of Coimbra, ${ }^{b}$ Center for Neurosciences of Coimbra and ${ }^{c}$ Neurological Unit, \\ University Hospital of Coimbra, Coimbra, Portugal
}

\section{Key Words}

Alzheimer's disease - Mitochondrial DNA · NADH

dehydrogenase subunit $1 \cdot 16 \mathrm{~S}$ rRNA $\cdot$ Nucleotides

\begin{abstract}
Alzheimer's disease ( $A D)$ is the most common neurodegenerative disorder associated with dementia in late adulthood. Mitochondrial respiratory chain impairment has been detected in the brain, muscle, fibroblasts and platelets of $A D$ patients, indicating a possible involvement of mitochondrial DNA (mtDNA) in the etiology of the disease. Several reports have identified mtDNA mutations in $A D$ patients, but there is no consensual opinion regarding the cause of the impairment. We have studied mtDNA NADH dehydrogenase subunit 1 nucleotides 3337-3340, searching for mutations. Our study group included 129 AD patients and 125 healthy age-matched controls. We have found alterations in two AD patients: one had two already known mtDNA modifications (3197 T-C and 3338 T-C) and the other a novel transition (3199 T-C) which, to our knowledge, has not been described before.
\end{abstract}

Copyright $(C 2005$ S. Karger AG, Basel

\section{Introduction}

In the last few years, some evidence has been found for energy metabolism deficiency and mitochondrial DNA (mtDNA) alterations contributing to the etiopathogenesis of Alzheimer's disease (AD). In 1992, Lin et al. [1] identified, in AD patients, a G-A transition and a G-T transversion, both at nucleotide 5460 of mtDNA NADH dehydrogenase subunit 2 gene, but these findings were not confirmed [2]. Later, Shoffner et al. [3] reported four polymorphisms (nucleotides 3196, 3397, 4336 and 956-965 insertion), having special importance, and the tRNA (Gln) variant at position 4336 that modifies a moderately conserved nucleotide. Kösel et al. [4] found in patients with Parkinson's disease (PD) a known missense mutation at nucleotide 3338 of the $N A D H$ dehydrogenase subunit 1 (ND1) mtDNA gene that changes the amino acid valine to alanine. This mutation has previously been described by Chalmers et al. [5] in a control subject, and it was absent in subsets of our PD [6] and frontotemporal dementia [7] patients.

We analyzed mtDNA ND1 nucleotides 3337-3340 in 129 AD patients and 125 healthy age-matched control subjects, in order to determine if mtDNA ND1 is related to $\mathrm{AD}$. We also tried to find an additional peripheral genetic risk factor for the disease.

\section{KARGER}

Fax +4161306 1234 E-Mail karger@karger.ch www.karger.com
Manuela Grazina

Biochemistry Institute

Faculty of Medicine, University of Coimbra, Rua Larga

PT-3004-504 Coimbra (Portugal)

Tel. +351 239 820190, Fax +351 239 822776, E-Mail mgrazina@ci.uc.pt 


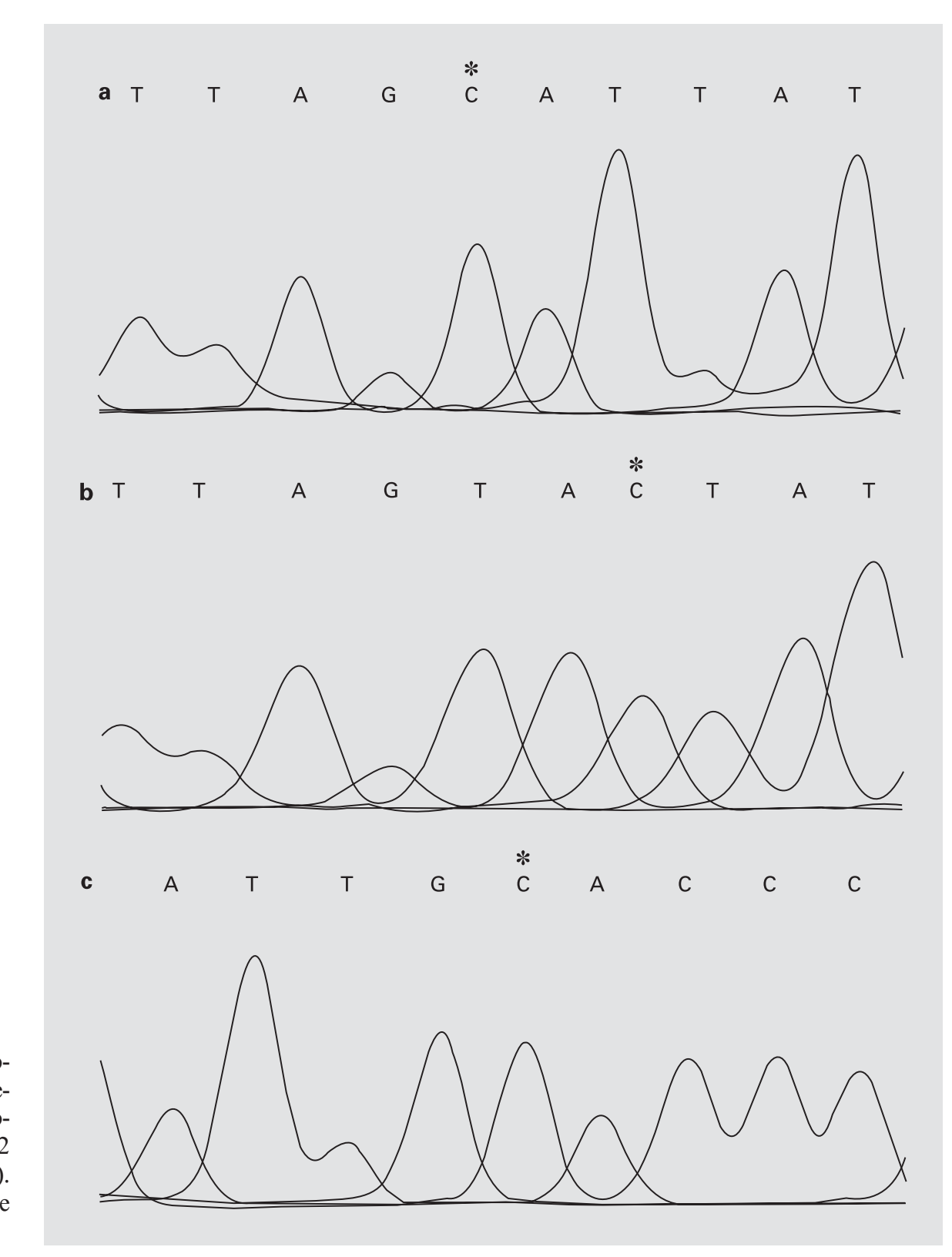

Fig. 1. Results of fluorescence-based automated sequencing analysis. a mtDNA sequence of $\mathrm{P} 1$ surrounding the nucleotide $3197 \mathrm{C}(*)$. b mtDNA sequence of P2 surrounding the nucleotide 3199C (*). c mtDNA sequence of P1 surrounding the nucleotide $3338 \mathrm{C}(*)$.

\section{Methods}

One hundred and twenty-nine Caucasian patients (80 female and 49 male; mean age: $69.6 \pm 8.9$ years, range: $41-89$ years; mean age at onset of AD: $65.5 \pm 9.3$ years, range: $35-86$ years) with the diagnosis of probable $\mathrm{AD}$, as defined by standard criteria $[8,9]$ and followed at the Neurological Unit of the University Hospital of Coimbra, were randomly selected for this study. The patients had at least 1-year history of cognitive decline confirmed by neuropsychological assessment, and positive family history was reported in 40 patients (31\%). Family history was considered positive when a first degree relative had dementia. Early onset AD was considered when the patient started the disease course before reaching the age of 65 years. Global cognitive impairment was quantified using the
Mini-Mental State Examination (MMSE) [10]. The mean MMSE score was $12.1 \pm 7.9$ (range 0-29) and global dementia severity was staged in accordance with the Clinical Dementia Rating (CDR) [11, 12] where CDR 0 indicates no impairment and CDR 0.5, 1, 2 and 3 indicate questionable, mild, moderate and severe dementia, respectively. Our patient group included 35 patients with CDR 1, 55 with CDR 2 and 39 with CDR 3. One hundred and twenty-five healthy age-matched Caucasian control subjects, free of neurological disorders ( 73 female and 52 male; mean age: $65.2 \pm 13.0$ years, range: $37-90$ years) were recruited among the staff and accompanying persons of the patients. Informed consent was obtained from all patients and controls, according to the University Hospital Ethical Council guidelines. Total cellular DNA was isolated from peripheral leukocytes (105 patients and 123 controls), cultured fibro- 
blasts ( 7 patients and 1 control) and both peripheral leukocytes and cultured fibroblasts (17 patients and 1 control) by standard procedures. PCR and RFLP of patient and control DNA samples were performed as described previously [6]. When a positive result was found, the fragments of mtDNA were sequenced as reported before [7] and sequences were compared with the revised Cambridge sequence of the human mitochondrial genome [13]. In order to verify if the PCR product was an amplification of mtDNA genes or nuclear pseudogenes, we also analyzed total cellular DNA isolated from $\rho^{0}$ cells. DNA analyses were performed blind to the diagnosis, and subject identities were known only after the results had been completed.

\section{Results and Discussion}

Only one AD patient (P1) showed a homoplasmic mtDNA modification at nucleotides $3337-3340$ by PCRRFLP analysis. He was 54 years old, and the onset of disease occurred at 53 years. Although the MMSE score was in the normal range (29) at the first visit, neuropsychological assessment confirmed a deterioration in memory and language, and the patient was classified as mildly demented using CDR (1); there was no family history reported. Additionally, an unexpected pattern at agarose gel electrophoresis occurred in another sample: fragments presenting lower molecular weight (141 bp $+69 \mathrm{bp})$ than the wild-type ( $210 \mathrm{bp}+79 \mathrm{bp}$ ) or mutant (289 bp) bands, together with the 79-bp band, were found in a 68-year-old male AD patient (P2) who scored 22 and 1 on the MMSE and CDR, respectively. His age at disease onset was 65 years, and he had no family history. Sequence analysis confirmed the PCR-RFLP result. P1 presented a known missense transition T-C at nucleotide 3338 of the $\mathrm{mtD}$ NA ND1 gene, which promotes the change of valine to alanine in the peptide chain (fig. 1). This change is considered a harmless polymorphism, based on studies of amino acid residue substitutions [14], and was found through sequence analysis in 1 patient with hypertrophic cardiomyopathy [15, 16], 1 with PD [4] and 1 multiple sclerosis control subject [5]. This is a highly conserved nucleotide among the hominoid primates (data not shown), as well as nucleotides 3339 and 3340, which do not occur with nucleotide 3337 . Additionally, P1 presented another known T-C transition at nucleotide 3197 of the 16S rRNA mtDNA gene (fig. 1), which had previously been described [17] in a patient with ischemic colitis and in $\mathrm{AD}, \mathrm{PD}, \mathrm{AD}+\mathrm{PD}$ patients and Caucasian controls [18] as a polymorphism, also reported as associated with the haplogroup U5, present in the European populations [19], and very weakly conserved among hom- inoid primates (data not shown). P2 presented a normal sequence at nucleotides 3337-3340 (GTAC), but we have found a novel homoplasmic alteration at nucleotide 3199 of the 16S rRNA mtDNA gene (fig. 1), a T-C transition, originating a cleavage site (GTAC sequence) recognized by Csp 6I endonuclease and originating altogether three bands with 141, 79 and $69 \mathrm{bp}$, after electrophoresis. This is a very weakly conserved nucleotide in hominoid primates since there is a $\mathrm{C}$ in the genus Pan (chimpanzee and bonobo), a T in Gorilla gorilla and Homo sapiens and a nucleotide deletion or a $\mathrm{C}$ in Pongo pygmaeus (data not shown). To our knowledge, this nucleotide change is reported here for the first time, and it seems unlikely that it is a causative mutation. We have screened all the other patients and the 125 controls for the presence of this new variant, but no other positive samples were found. Additionally, there was no amplification of the total cellular DNA isolated from $\rho^{0}$ cells, confirming that we were analyzing mtDNA and not nuclear pseudogenes.

\section{Conclusion}

mtDNA ND1 nucleotides 3337-3340 seem unlikely to be a primary risk factor for $\mathrm{AD}$ in the population under study (central region of Portugal), which is in agreement with the current literature, but does not rule out the possible contribution of $N D 1,16 S r R N A$, or any other mtDNA gene to the pathogenesis of AD. In fact, it is possible that distinct combinations of nonmutated electron transport chain components do not function identically; being so, nonpathogenic mtDNA variations could contribute to AD risk, while at the same time explaining why associations between mtDNA polymorphism and AD are difficult to establish [20].

\section{Acknowledgements}

We would like to acknowledge Prof. A. Münich, Dr. P. Rustin and Dr. A. Rötig for providing $\rho^{0}$ cell DNA. We thank the Histocompatibility Centre of Coimbra for providing the facilities for sequence analysis. This work was partially supported by a scholarship from the Fundação para a Ciência e Tecnologia - Fundo Social Europeu, III Quadro Comunitário de apoio (PRAXIS XXI/ BD/4049/94) and by a scholarship (prized project on Brain Aging, Alzheimer Disease and Other Dementia) from the Sociedade Portuguesa de Neurociências (sponsored by Pfizer laboratories). 


\section{References}

1 Lin F-H, Lin R, Wisniewski HM, Hwang Y-W, Grundke-Iqbal I, Healy-Louie G, Iqbal K: Detection of point mutations in codon 331 of mitochondrial NADH dehydrogenase subunit 2 in Alzheimer's brain. Biochem Bioph Res Commun 1992;182:238-246.

2 Petruzzella V, Chen X, Schon EA: Is a point mutation in the mitochondrial ND2 gene associated with Alzheimer's disease? Biochem Bioph Res Commun 1992;186:491-497.

3 Shoffner JM, Brown MD, Torroni A, Lott MT, Cabell MF, Mirra SS, Beal MF, Yang C-C, Gearing M, Salvo R, Watts RL, Juncos JL, Hansen LA, Crain BJ, Fayad M, Reckord CL, Wallace DC: Mitochondrial DNA variants observed in Alzheimer disease and Parkinson disease patients. Genomics 1993;17:171-184.

4 Kösel S, Grasbon-Frodl EM, Mautsch U, Egensperger R, von Eitzen U, Frishman D, Hofmann S, Gerbitz KD, Mehraein P, Graeber MB: Novel mutations of mitochondrial complex I in pathologically proven Parkinson disease. Neurogenetics 1998;1:197-204.

5 Chalmers RM, Robertson N, Kellar-Wood H, Compston DAS, Harding AE: Sequence of the human homologue of a mitochondrially encoded murine transplantation antigen in patients with multiple sclerosis. J Neurol 1995;242: 332-334.

6 Grazina M, Silva F, Januário C, Oliveira M, Cunha L, Oliveira C: Parkinson's disease and mitochondrial DNA NADH dehydrogenase subunit 1 nucleotides 3337-3340: Study in a population from the central region of Portugal (Coimbra). Eur Neurol 2003;50:60-61.
7 Grazina M, Silva F, Santana I, Santiago B, Mendes C, Simões M, Oliveira M, Cunha L, Oliveira C: Frontotemporal dementia and mitochondrial DNA transitions. Neurobiol Dis 2004; 15:6-11.

8 American Psychiatric Association: Diagnostic and Statistical Manual of Mental Disorders, ed 4. Washington, APA, 1994.

9 McKhann G, Drachman D, Folstein M, Katzman R, Price D, Stadlan EM: Clinical diagnosis of Alzheimer's disease. Report of the NINCDS-ARDA work group under the auspices of Department of Health and Human Services Task Force on Alzheimer's disease. Neurology 1984;34:939-944.

10 Folstein M, Folstein S, McHugh P: Mini-Mental State. A practical method for grading the cognitive state of patients for the clinician. $\mathrm{J}$ Psychiatr Res 1975;12:189-198.

11 Hughes CP, Berg L, Danzinger W, Coben LA, Martin RL: A new clinical scale for the staging of dementia. Br J Psychiatry 1982;140:566572.

12 Berg L: Clinical dementia rating (CDR). Psychopharmacol Bull 1988;24:637-639.

13 Andrews RM, Kubacka I, Chinnery PF, Lightowlers RN, Turnbull DM, Howell N: Reanalysis and revision of the Cambridge reference sequence for human mitochondrial DNA. Nat Genet 1999;23:147.

14 Bordo D, Argos P: Suggestions for 'safe' residue substitutions in site-directed mutagenesis. J Mol Biol 1991;217:721-729.
15 Ozawa T, Tanaka M, Sugiyama S, Ino H., Ohno K, Hattori K, Ohbayashi T, Ito T, Deguchi H, Kawamura K, Nakane Y, Hashiba K: Patients with idiopathic cardiomyopathy belong to the same mitochondrial DNA gene family of Parkinson's disease and mitochondrial encephalomyopathy. Biochem Bioph Res Co 1991;177:518-525.

16 Obayashi T, Hattori K, Sugiyama S, Tanaka M, Tanaka T, Itoyama S, Deguchi H, Kawamura K, Koga Y, Toshima H, Takeda N, Nagano M, Ito T, Ozawa T: Point mutations in mitochondrial DNA in patients with hypertrophic cardiomyopathy. Am Heart J 1992;124:12631269.

17 Hess J, Burkhard P, Morris M, Lalioti M, Myers $\mathrm{P}$, Hadengue A: Ischaemic colitis due to mitochondrial cytopathy. Lancet 1995;346: 189-190.

18 Brown MD, Shoffner JM, Kim YL, Jun AS, Graham BH, Cabell MF, Gurley DS, Wallace DC: Mitochondrial DNA sequence analysis of four Alzheimer's and Parkinson's disease patients. Am J Med Genet 1996;61:283-299.

19 Herrnstadt C, Elson JL, Fahy E, Preston G, Turnbull DM, Anderson C, Ghosh SS, Olefsky JM, Beal MF, Davis RE, Howell N: Reducedmedian-network analysis of complete mitochondrial DNA coding-region sequences for the major African, Asian, and European haplogroups. Am J Hum Genet 2002; 70:11521171.

20 Swerdlow RH, Kish SJ: Mitochondria in Alzheimer disease. Rev Neurobiol 2002;53:341385 . 
Copyright: S. Karger AG, Basel 2005. Reproduced with the permission of S. Karger AG, Basel. Further reproduction or distribution (electronic or otherwise) is prohibited without permission from the copyright holder. 
Copyright: S. Karger AG, Basel 2005. Reproduced with the permission of S. Karger AG, Basel. Further reproduction or distribution (electronic or otherwise) is prohibited without permission from the copyright holder. 